\title{
Spatial Spillover Effects of Mega-City Lockdown Due to Covid-19 Outbreak: Evidence from Turkey
}

\section{Fatih CELEBIOGLU *}

Received: August 24, 2020 Revised: November 20, 2020 Accepted: November 25, 2020.

\begin{abstract}
With the Covid-19 outbreak, academic studies have been started to calculate the economic effects of the outbreak. Since it is not possible to determine when epidemics/pandemics (or large magnitude earthquakes, etc.) occur, their negative economic effects cannot be precisely predicted. Decreasing consumption and supply at the same time, breaking the supply chain, closing businesses and increasing unemployment are rapidly disrupting economic conditions. The measures are mostly related to issues at the macroeconomic level. If a full curfew is imposed throughout the country, economists are working on how it will have an impact on the economy of the whole country. However, the analysis of the effects at the regional level is discussed secondarily. The aim of this study is to simulate the effects of an economic lock-down that might take place in two important mega cities such as Istanbul and Izmir. As a result of this analysis made using spatial econometrics tools; in the event of a lockdown (or earthquake) in mega cities such as istanbul and/or Izmir, there will be major economic difficulties that will spread wave by wave to the neighbouring cities and then eventually to the whole country.
\end{abstract}

Keywords: Covid-19, Mega-city, Lockdown, Spatial Econometrics, Spillover Effects

JEL Code Classifications: R11, R12, O20

UDC: 332

DOI: https://doi.org/10.17015/ejbe.2020.026.05.

\footnotetext{
*Associate Professor, Independent Researcher, Turkey. Email: fcelebioglu@hotmail.com 


\section{Introduction}

Covid-19 pandemic is affecting all the countries in the world. WHO (2020) declared that as of May 01,2020, the total number of confirmed globally cases of COVID-19 reached $3,175,207$, whereas the total number of deaths was 224,172 .

With the emergence of the Covid-19 outbreak in Wuhan (China) and its rapid spread to throughout the world, governments in all countries implemented curfews and took measures to restrict economic activities. As a result, economic growth is expected to decline and unemployment will increase rapidly.

Although the outbreak began in December 2019, it was declared by the World Health Organization (WHO) as a pandemic on March 11, 2020. Shortly after the first case was seen in Turkey on March 10, 2020, the measures were increased. Curfew was imposed on people aged over 65 and under 20. Despite much controversy, the curfew was not fully implemented. Outbreak in Turkey was more effective in metropolitan cities where the population density is high. The data ${ }^{1}$ of the Ministry of Health show that İstanbul ${ }^{2}$ lead the way.

Why does the Turkish government not willing to implement a long-term curfew in metropolitan cities instead of a short-term and limited curfew? The most important reason is that these cities are Turkey's economic centres. If any lockdown occurs in these cities due to an epidemic or other reason (for example, the great Istanbul earthquake that has been expected for years), it will result in huge losses in gross domestic product at the provincial level for the rest of the country. These cities are a source of income for other cities as they make a large purchase from other cities for their own production and consumption.

The main purpose of the paper is to explain the spatial spillover economic effects of mega-city lockdown due to Covid-19 outbreak in Turkey.

\section{Literature}

Since the Covid-19 outbreak began to spread around the world, many economists quickly began to publish studies analysing the economic effects of the epidemic.

The vast majority of these studies focus on scenarios, the possible macroeconomic effects, and commodity prices as a result of the Covid-19 outbreak (McKibbin \& Fernando, 2020a \& 2020b; Arezki \& Nguyen, 2020; Fernandes, 2020; Ozili \& Arun, 2020). On the other hand, Baldwin and Tomiura (2020) analyse the problems arising

\footnotetext{
${ }^{1}$ Although the Ministry of Health did not regularly publish data at the provincial level, it was announced by the Minister that Istanbul and Izmir were in the first two places. Please see:

https://tr.euronews.com/2020/04/03/turkiye-de-en-cok-koronavirus-covid-19-vakasinin-goruldugu-10kent

${ }^{2}$ Please see the map that shows geographically all provinces of Turkey in the appendix.
} 
in national and international trade in goods and services due to the epidemic. Beck (2020) works on global financial side and Toda (2020) studies on stock pricing and labour supply shock based on asset pricing model. Voth (2020) focuses on relations between trade and travel in the time of epidemics. Elgin et al. (2020) develops Covid19 Economic Stimulus Index (CESI). Lustig and Mariscal (2020) compare the economic effects of the outbreak to the 2008 global crisis. Sumner et al. (2020) focus on the estimates of the impact of COVID-19 on global poverty. Atkeson (2020) works on economic impact of Covid-19 in the US economy. Guerrieri et al. (2020) investigates whether or not negative supply shocks cause demand shortages.

Guliyev (2020) examines the factors affecting COVID-19 together with the spatial effects, and use spatial panel data models to determine the relationship among the variables including their spatial effects. Using spatial panel models, he analyses the relationship between confirmed cases of COVID-19, deaths thereof, and recovered cases due to treatment.

Although there are studies (Huang et al., 2020; Kang et al., 2020) analysing the spatial spread of Covid-19, there are no publications addressing the spatial economic effects of the epidemic.

One of the rare studies based on city/province was on Tokyo. Inoue and Todo (2020) focus on the economic effects of a possible lockdown of Tokyo to prevent spread of COVID-19. Applying an agent-based model to the actual supply chains of nearly 1.6 million firms in Japan, they simulate what would happen to production activities outside Tokyo when production activities that are not essential to citizens' survival in Tokyo were to shut down for a certain period. They find that when Tokyo is locked down for a month, the indirect effect on other regions would be twice as large as the direct effect on Tokyo, leading to a total production loss of 27 trillion yen in Japan, or $5.3 \%$ of its annual GDP. Although the production shut down in Tokyo accounts for $21 \%$ of the total production in Japan, the lockdown would result in a reduction of the daily production in Japan by $86 \%$ in a month.

Although limited in number, some analyses on this subject were made on Turkey. Özatay and Sak (2020a) work on managing the economic consequences (especially tourism, unemployment and SMEs) of COVID-19. Açıkgöz and Günay (2020) explain potential impacts of the Covid-19 pandemic on the Turkish Economy and try to put forth possible economic and political scenarios for the post-pandemic world.

Özatay and Sak (2020b) try to answer how national income and economic growth would be affected, if the epidemic lasted long. According to their calculations, for a six-month epidemic, Turkish economy needs support up to 19 percent of GDP. If the duration of the outbreak increases to nine months, this value becomes 27 percent. Taymaz (2020) examines the impacts of the Covid-19 measures the on Turkish economy using input-output analysis. He makes estimation about the sectors whose activities are restricted and not restricted based on economic relations among the sectors. Relations between Covid-19 cases and the city sizes in Turkey were 
examined by Yigit (2020). Özatay and Sak (2020c) focus on the cost of it to the economy, if a curfew is imposed due to COVID-19.

Akcigit and Akgunduz (2020) present some evidence on the size and likely consequences of the sharp decline in demand that followed the beginning of the Covid-19 pandemic in Turkey. They use daily data on province-level credit card spending to estimate the size of the demand shock in each Turkish province. Their results show that the demand shock was sizeable, particularly in large cities like Istanbul. Assuming that the demand shock will last three months, they find an annual decline in total firm sales of $10 \%$ with considerable variation across provinces.

As can be seen in these studies, many economists focus on the effects of the epidemic at the macroeconomic level (inflation, GDP, growth rate, unemployment rate, current accounts, budget deficit etc.). However, there is not enough work on what regional economic impact will occur if mega-cities are locked down due to the epidemic. This study aims to fill the gap in this field.

\section{Importance of Istanbul and Izmir}

Turkey is a country with large regional disparity (Gezici \& Hewings, 2004; Celebioglu \& Dall'erba, 2010). In particular, the west of Turkey is in a better situation than other regions in terms of economic development. This situation of Western Anatolia can be clearly seen from all kinds of economic and social data. Especially Marmara and Aegean region are different from the others. Marmara region is the economic, financial and industrial epicentre of Turkey. Revenues are higher in these regions due to the population density, the development of trade and industrial sectors, and the impact of tourism (Celebioglu, 2010). According to the Socio-Economic Development Index (Acar, Bilen-Kazancik, Meydan, \& Işık, 2017), Istanbul ranks first and Izmir is third among the most developed provinces.

According to Turkish Statistical Institute - TURKSTAT (2020), population of provinces (first 10) in Turkey can be seen on Table 1 . İstanbul is the most populous city. The second city is Ankara, the capital of Turkey, and Izmir is in the third rank.

\section{Table 1. Population Numbers of Provinces in Turkey (2019)}

\begin{tabular}{lc}
\hline Provinces & Population Numbers \\
\hline İstanbul & $15,519,267$ \\
\hline Ankara & $5,639,076$ \\
\hline İzmir & $4,367,251$ \\
\hline Bursa & $3,056,120$ \\
\hline Antalya & $2,511,700$ \\
\hline Adana & $2,237,940$ \\
\hline Konya & $2,232,374$ \\
\hline Şanlıurfa & $2,073,614$ \\
\hline Gaziantep & $2,069,364$ \\
\hline Kocaeli & $1,953,035$ \\
\hline
\end{tabular}

Source: TURKSTAT (2020) 
Turkish Exporters Assembly - TiM (2020) dataset explains that the most powerful exporter city is İstanbul in 2019 in Turkey. İzmir is the fourth city in Turkey. İstanbul can be considered as the economic capital of Turkey. Factors such as population, commercial and financial data, industrial production, and intercontinental location support this claim. Although İstanbul has a special status, the status of İzmir, Turkey's 3rd-biggest metropolitan city, is similar to İstanbul.

\section{Table 2. Export Numbers of Provinces in Turkey (2019)}

\begin{tabular}{lc}
\hline Provinces & Export (thousand dollars) \\
\hline İstanbul & $70,101,911$ \\
\hline Kocaeli & $15,240,493$ \\
\hline Bursa & $14,987,146$ \\
\hline İzmir & $9,770,278$ \\
\hline Ankara & $8,303,474$ \\
\hline Gaziantep & $7,471,843$ \\
\hline Sakarya & $5,177,176$ \\
\hline Manisa & $4,450,434$ \\
\hline Denizli & $3,185,780$ \\
\hline Hatay & $2,841,678$ \\
\hline Kayseri & $2,050,133$ \\
\hline Konya & $2,013,869$ \\
\hline Adana & $1,918,852$ \\
\hline Mersin & $1,797,162$ \\
\hline Source: TiM (2020) &
\end{tabular}

The aim of this study is to simulate the effects of an economic lock-down that might take place in two important mega cities such as Istanbul and Izmir. Istanbul is the only city with a population of over 10 million and therefore considered a mega-city. Although the population of İzmir is not more than 10 million, it is included in the research both for industry-oriented economic structure of izmir and for comparison purposes. Ankara has a GDP predominantly in the service sector due to its public bureaucracy. As can be expected, even if every institution in the country lock downed, the capital's public bureaucracy has to work. For example, other developed cities such as Bursa and Kocaeli could be included in the study. However, these cities are already in the Marmara region and the hinterland of Istanbul.

\section{Data}

Province based gross domestic products (year 2018) dataset ${ }^{3}$ comes from Turkish Statistical Institute of Turkey. We use LN of provincial GDP (see at tables as LN_G).

\footnotetext{
3 Please see on the website:

https://data.tuik.gov.tr/Bulten/DownloadlstatistikselTablo?p=JFvsl/Gs8zW5PoXP1EbYn4l9eg55AalWpRG Y4hdv5imUA/33e1h9HevA5ifrZ/P1\&p2=KjruOLDCQX/hD7pBuoE8U6tbve7J3cqnr8XvA4UqtYPFU1jthtPuT 9GOP2MEpD9I\&type $=1$
} 
Inter-city trade dataset ${ }^{4}$ (year 2017) of İstanbul and İzmir comes from Entrepreneurial Information System of the Ministry of Industry and Technology. We consider the ratio of the purchases of Istanbul and Izmir from each province within the total purchases (see at tables as IST_BUY and IZ_BUY).

We have some limitations about the datasets. The institutions have not published the new versions of datasets after 2017 and 2018. However, the datasets we used as the economic weight of the provinces will not change in a short time. We use GeoDa Program to analyse spatial effects.

\section{Methodology}

In this section, we will explain spatial neighbours and spatial weight matrix, spatial autocorrelation, Moran's I value and bases of spatial econometric analysis.

\subsection{Spatial Weight Matrix and Spatial Neighbours}

Following Anselin (1988), spatial weight matrix is the necessary tool to impose a neighbourhood structure on a spatial dataset. As usual in the spatial statistics literature, neighbours are defined by a binary relationship ( 0 for non-neighbours, 1 for neighbours). We have used two basic approaches for defining neighbourhood: contiguity (shared borders) and distance. Contiguity-based weights matrices include rook and queen. Areas are neighbours under the rook criterion if they share a common border, not vertices. Distance-based weight matrices include distance bands and $k$ nearest neighbours. Based on these two concepts, we tried all the neighbourhood criteria of Queen, Rook, Distance $200 \mathrm{~km}$, Distance $250 \mathrm{~km}$ and Distance $300 \mathrm{~km}$. Since we found the best results in a distance $250 \mathrm{~km}$ neighbourhood, we decided to use the "distance $250 \mathrm{~km}$ " weight matrix which defines as neighbours all the provinces located within a great circle distance with a cut-off of $250 \mathrm{~km}$. Distance metric is based on ARCDISTANCE (km).

$$
w_{i j}=\left\{\begin{array}{cc}
1, & 0 \leq d_{i j} \leq d \\
0, & d_{i j}>d
\end{array}\right.
$$

where $d_{\text {_ }} \mathrm{ij}$ is great circle distance between centroids of region $\mathrm{i}$ and $\mathrm{j}$. The weight matrices are based on the centroid distances, $d_{-} i j$, between each pair of spatial units $\mathrm{i}$ and $\mathrm{j}$.

\subsection{Moran's I for Global Spatial Autocorrelation}

Anselin and Berra (1998) describe spatial autocorrelation as coincidence of value similarity with locational similarity. In other words, high or low values for a random variable tend to cluster in space (positive spatial autocorrelation), or locations tend to be surrounded by neighbours with very dissimilar values (negative spatial

\footnotetext{
${ }^{4}$ Please see on the website: $\underline{\text { https://gbs.sanayi.gov.tr/AnaSayfa.aspx }}$
} 
autocorrelation). Positive spatial autocorrelation operationalizes Tobler's First Law of Geography whereby closer areas are more similar in value than distant ones. Negative spatial autocorrelation exists when high values correlate with low neighbouring values and vice versa.

Spatial autocorrelation refers to the correlation of a variable with itself in space. It can be positive (when high values correlate with high neighbouring values or when low values correlate with low neighbouring values) or negative (spatial outliers for high-low or low-high values). Note that positive spatial autocorrelation can be associated with a small negative value (e.g., -0.01) since the mean in finite samples is not cantered on 1. Spatial autocorrelation analysis includes tests and visualization of both global (test for clustering) and local (test for clusters) Moran's I statistic (Anselin et al., 2006).

Global spatial autocorrelation is a measure of overall clustering and it is measured here by Moran's I. It captures the extent of overall clustering that exists in a dataset. It is assessed by means of a test of a null hypothesis of random location. Rejection of this null hypothesis suggests a spatial pattern or spatial structure, which provides more insights into data distribution, that what a quartile map or box plot does. For each variable, it measures the degree of linear association between its value at one location and the spatially weighted average of neighbouring values (Anselin et al. 2007; Anselin 1995) and is formalized as follows:

$$
I_{t}=\frac{\sum_{i=1}^{n} \sum_{j=1}^{n} \dot{w}_{i j}(k) x_{i t} x_{j t}}{\sum_{i=1}^{n} \sum_{j=1}^{n} x_{i t} x_{j t}}
$$

Where $w_{-}{ }_{i} j$ is the (row-standardized) degree of connection between the spatial units $i$ and $j$ and $x_{-} i j$ is the variable of interest in region $i$ at year $t$ (measured as a deviation from the mean value for that year). Values of I larger (smaller) than the expected value $E(I)=-1 /(n-1)$ indicate positive (negative) spatial autocorrelation.

\subsection{Spatial Econometric Analysis}

We explain spatial econometrics dimensions of economic lockdown of İstanbul and İmir due to Covid-19 or large magnitude earthquake. For this reason, spatial lag and spatial error models are tested for the variables.

Spatial autocorrelation analysis is completed by means of composing spatial weights. Evaluation of spatial autocorrelation is applied to ordinary least-squares regression. Maximum likelihood analysis is used to measure spatial error and lag models (Anselin et al., 2006; Altay \& Çelebioğlu, 2015) are the two main types of spatial regression models (Figure 1 ).

According to the spatial lag model, the degree of dependent variable "a" at a region " $X$ " is affected by the degree of that same dependent variable at the bordering region " $Y$ ". Beside the dependent variable $y$ in place $i$ is affected by the independent variables in both place $i$ and $j$. 

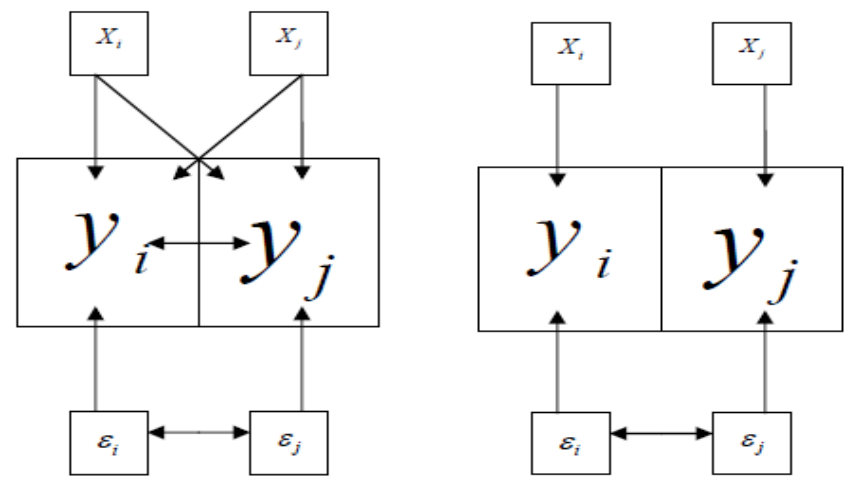

Figure 1. Spatial Lag Model (on left) and Spatial Error Model (on right)

Source: GeoDa: Spatial Regression (2020) Spatial Structures in the Social Sciences. Retrieved February 20, 2020 from https://s4.ad.brown.edu/Resources/Tutorial/Modul2/GeoDa3FINAL.pdf.

This is a statistical expression of "spatial spillover". For instance, the rate of unemployment in a region may be affected by the rate of unemployment at a bordering region. Following Anselin (2003), incorporates spatial effects by including a spatially lagged dependent variable as an additional predictor:

$$
y=\rho W y+x \beta+\varepsilon
$$

where $w_{-} y$ is spatially lagged dependent variable for weights matrix, is a matrix of observations on explanatory variables, $\varepsilon$ is a vector of error terms, is the spatial coefficient. If there is no spatial dependence, and y does not depend on neighbouring y values, $\rho=0$.

Incorporates spatial effects through error term;

$$
\begin{aligned}
& y=x \beta+\varepsilon \\
& \varepsilon=\lambda W \varepsilon+\zeta
\end{aligned}
$$

Where $\varepsilon$ is the vector of error terms, spatially weighted using the weight matrix ( $W$ ), $\lambda$ is the spatial error coefficient and $\zeta$ is a vector of uncorrelated error terms. If there is no spatial correlation between the errors, then $\lambda=0$.

The model then changes to:

$$
y=x \beta+(I-\lambda W)^{-1} \zeta
$$

According to (Anselin, 2005), spatial regression model selection begins considering the standard (i.e., not the robust forms) LM-Error and LM-Lag test statistics. If neither rejects the null hypothesis, stick with the OLS results. It is likely that in this case, the Moran's I test statistic will not reject the null hypothesis either. If one of the LM test 
statistics rejects the null hypothesis, and the other does not, then the decision is straightforward as well: estimate the alternative spatial regression model that matches the test statistic that rejects the null. If LM-Error rejects the null, but LM-lag does not, estimate a spatial error model, and vice versa. When both LM test statistics reject the null hypothesis, proceed to the bottom part of the graph and consider the robust forms of the test statistics. Typically, only one of them will be significant or one will be orders of magnitude more significant than the other (e.g., $p<0.00000$ compared to $p<0.03)$. In that case, the decision is simple: estimate the spatial regression model matching the (most) significant statistic. In the rare instance that both would be highly significant, go with the model with the largest value for the test statistic.

\section{Findings}

If a lockdown takes place in Istanbul and Izmir due to Covid-19, these mega-cities cannot purchase goods and services from other provinces. In this case, a decrease will occur in the incomes of the provinces other than these two mega cities. We can see this in OLS estimates. First, we can look at the OLS estimates of Istanbul. In OLS regressions, the level of significance of independent variables in regressions ( $p=$ 0.000 ) is quite high.

As seen in Table 3, according to Istanbul's OLS regression results, the purchases (also including intra-istanbul purchases) made by Istanbul from the provinces within one year contribute $6.9 \%$ to the gross domestic product of those provinces. The opposite can also be said. In other words, if the economy of Istanbul experiences a full lockdown, the gross domestic product of other provinces decreases by $6.99 \%$. According to Izmir's OLS regression results, the purchases of goods and services from İmir (including intra-Izmir purchases) affect the gross domestic product of the provinces by $9 \%$. Therefore, a full lockdown process that İzmir will experience can decrease the gross domestic product level of other provinces by $9 \%$.

Although Izmir has a smaller economic volume than Istanbul, it has a greater impact on other provinces through its acquisitions. The main reason for this can be attributed to the fact that intra-Istanbul purchases are larger than intra-Izmir purchases. The fact that lockdown in one province has more effect than lockdown in another province is not only related to the size of the province. Because the forward - backward linkages of the sectors in each province are different from each other. How many of these sectoral forward and backward linkages are in neighbouring provinces are important in determining the impact. Izmir's forward and backward linkages in its neighbouring provinces may be greater than Istanbul's forward and backward linkages in its neighbouring provinces. This may also be the subject of other research. 
Table 3. Regression Results for Istanbul and Izmir

\begin{tabular}{|c|c|c|c|c|c|c|}
\hline & \multicolumn{2}{|c|}{ OLS } & \multicolumn{2}{|c|}{$\begin{array}{l}\text { OLS with weight } \\
\text { matrix }\end{array}$} & \multicolumn{2}{|c|}{ Spatial Lag Model } \\
\hline & Istanbul & Izmir & Istanbul & Izmir & Istanbul & Izmir \\
\hline R-squared & 0.242 & 0.254 & 0.243 & 0.254 & 0.355 & 0.344 \\
\hline Adjusted R-squared & 0.233 & 0.244 & 0.233 & 0.244 & - & - \\
\hline F-statistic & $\begin{array}{c}25.312 \\
(0.0003) \\
\end{array}$ & $\begin{array}{c}26.903 \\
(0.0002) \\
\end{array}$ & $\begin{array}{c}25.312 \\
(0.0001) \\
\end{array}$ & $\begin{array}{c}26.903 \\
(0.0002) \\
\end{array}$ & - & - \\
\hline Log likelihood & -111.63 & -111.02 & -111.63 & -111.02 & -106.142 & -106.655 \\
\hline Akaike info criterion & 227.26 & 226.03 & 227.26 & 226.03 & 218.283 & 219.311 \\
\hline Schwarz criterion & 232.05 & 230.82 & 232.05 & 230.82 & 225.467 & 226.494 \\
\hline Coefficient & $\begin{array}{l}0.0699 \\
(0.000)\end{array}$ & $\begin{array}{c}0.090 \\
(0.000) \\
\end{array}$ & $\begin{array}{l}0.0699 \\
(0.000) \\
\end{array}$ & $\begin{array}{c}0.090 \\
(0.000) \\
\end{array}$ & $\begin{array}{l}0.0659 \\
(0.000) \\
\end{array}$ & $\begin{array}{c}0.0823 \\
(0.0000) \\
\end{array}$ \\
\hline $\begin{array}{l}\text { Multicollinearity } \\
\text { Condition Number }\end{array}$ & 1.171 & 1.220 & 1.171 & 1.220 & - & - \\
\hline Jarque-Bera & $\begin{array}{l}2.7328 \\
(0.255) \\
\end{array}$ & $\begin{array}{l}1.8250 \\
(0.401) \\
\end{array}$ & $\begin{array}{l}2.7328 \\
(0.255) \\
\end{array}$ & $\begin{array}{l}1.8250 \\
(0.401) \\
\end{array}$ & - & - \\
\hline Breusch-Pagan test & $\begin{array}{l}0.0868 \\
(0.768) \\
\end{array}$ & $\begin{array}{l}2.9717 \\
(0.085) \\
\end{array}$ & $\begin{array}{l}0.0868 \\
(0.768) \\
\end{array}$ & $\begin{array}{l}2.9717 \\
(0.085) \\
\end{array}$ & $\begin{array}{c}0.0852 \\
(0.7704) \\
\end{array}$ & $\begin{array}{c}4.0914 \\
(0.04310) \\
\end{array}$ \\
\hline $\begin{array}{l}\text { Koenker-Bassett } \\
\text { test }\end{array}$ & $\begin{array}{l}0.0911 \\
(0.762)\end{array}$ & $\begin{array}{l}3.2450 \\
(0.072) \\
\end{array}$ & $\begin{array}{l}0.0911 \\
(0.762) \\
\end{array}$ & $\begin{array}{l}3.2450 \\
(0.072) \\
\end{array}$ & - & - \\
\hline Moran's I (error) & - & - & $\begin{array}{l}5.3850 \\
(0.000) \\
\end{array}$ & $\begin{array}{c}4.2486 \\
(0.0002) \\
\end{array}$ & - & - \\
\hline $\begin{array}{l}\text { Lagrange Multiplier } \\
\text { (lag) }\end{array}$ & - & - & $\begin{array}{l}22.848 \\
(0.000) \\
\end{array}$ & $\begin{array}{l}18.1909 \\
(0.0002) \\
\end{array}$ & - & - \\
\hline Robust LM (lag) & - & - & $\begin{array}{l}3.2364 \\
(0.072) \\
\end{array}$ & $\begin{array}{l}7.8794 \\
(0.005) \\
\end{array}$ & - & - \\
\hline $\begin{array}{l}\text { Lagrange Multiplier } \\
\text { (error) }\end{array}$ & - & - & $\begin{array}{l}19.6255 \\
(0.0001) \\
\end{array}$ & $\begin{array}{c}11.7170 \\
(0.001) \\
\end{array}$ & - & - \\
\hline Robust LM (error) & - & - & $\begin{array}{l}0.0138 \\
(0.907) \\
\end{array}$ & $\begin{array}{l}1.4055 \\
(0.236) \\
\end{array}$ & - & - \\
\hline $\begin{array}{l}\text { Lagrange Multiplier } \\
\text { (SARMA) }\end{array}$ & - & - & $\begin{array}{l}22.8620 \\
(0.0001) \\
\end{array}$ & $\begin{array}{l}19.5964 \\
(0.0001) \\
\end{array}$ & - & - \\
\hline Lag coefficient (Rho) & - & - & - & - & $\begin{array}{c}0.5099 \\
(0.0016) \\
\end{array}$ & $\begin{array}{l}0.4614 \\
(0.008) \\
\end{array}$ \\
\hline $\begin{array}{l}\text { Likelihood Ratio } \\
\text { Test }\end{array}$ & - & - & - & - & $\begin{array}{l}10.9765 \\
(0.001) \\
\end{array}$ & $\begin{array}{l}8.7228 \\
(0.003) \\
\end{array}$ \\
\hline
\end{tabular}

Note: Probability values are in the brackets.

It is known that the economy cannot be lock-down completely. People have to consume food, electricity and water to survive. In addition, most of the public institutions have to work. Therefore, the main purpose here is to determine the upper limit of the effect that will occur as a result of a lockdown.

When OLS regression results with weight matrix (for Dis_250) in Table 3 are examined, it is seen that Spatial Lag Model comes to the fore as a result of both regression analyses. Because the level of significance $(p=0.00002)$ of Lagrange 
Multiplier-LAG is higher than that of Lagrange Multiplier-ERROR ( $p=0.00062$ ). For this reason, Spatial Lag Model is run for both İstanbul and İzmir.

For İstanbul and İzmir, Table 3 show also Spatial Lag Model results. The table displays that the Lag coefficient (Rho)'s value is 0.509996 and it is highly significant $(p=0.00156)$ for Istanbul. This means that when İstanbul's GDP and its purchases increase by one unit, the gross domestic product in the neighbouring provinces increases by $0.51 \%$. If we say the opposite, when the GDP and purchases of Istanbul decrease by one unit, the gross domestic product in the neighbouring provinces will decrease by $0.51 \%$.

As mentioned above, in the non-spatial OLS regression, the average contribution of Istanbul's purchases to the gross domestic product in 81 provinces were almost 0.07 .

Table 3 also gives that Lag coefficient (Rho)'s value is 0.461356 and it is highly significant $(p=0.00745)$ for Izmir. This means that when Izmir's GDP and its purchases increase by one unit, the gross domestic product in the neighbouring provinces increases by $0.46 \%$. If we say the opposite, when the GDP and purchases of Izmir decrease by one unit, the gross domestic product in the neighbouring provinces will decrease by $0.46 \%$. As it is mentioned above, in OLS regression without spatial weights, the average contribution of Istanbul's purchases to the gross domestic product in 81 provinces was only 0.09 .

The neighbouring provinces of İstanbul (see the Connectivity Map 1 in Figure 2) mostly consist of crowded industrial and touristic cities (Kocaeli, Bursa, Adapazarı, Tekirdağ, Balıkesir, Bilecik etc.). There is a strong interaction among its neighbours and İstanbul. A lockdown to be implemented in istanbul will have huge negative economic impacts on the neighbours of this mega-city.

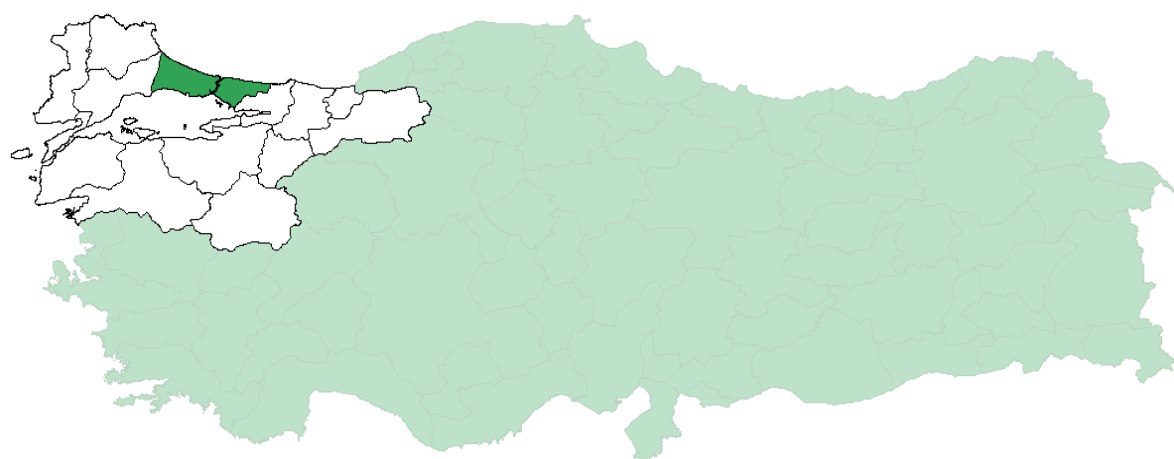

Figure 2. Connectivity Map 1- Neighbors of istanbul (250 km)

The neighbouring provinces of İzmir (see the Connectivity Map 2 in Figure 3) mostly consist of crowded industrial, agricultural, touristic cities (Manisa, Bursa, Aydın, Muğla, Balıkesir, Denizli, Uşak etc.). There is a strong interaction among its 
neighbours and Izmir. A lockdown to be implemented in İzmir will have huge negative economic impacts on the neighbours of this mega-city.

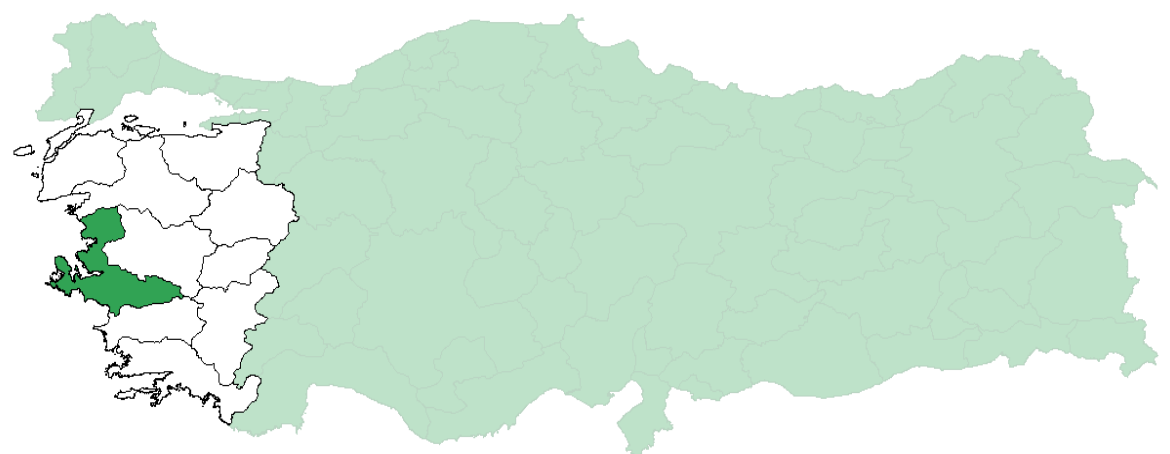

\section{Figure 3. Connectivity Map 2 - Neighbours of İzmir (250 km)}

\section{Conclusions}

The Covid-19 epidemic both threatens people's lives and harms the economies of countries to an unprecedented degree. Many economists try to calculate the size of the negative economic effects and the burden of the measures taken. This study is intended to calculate what negative spatial spillover economic effects may take place in a mega-city lockdowns due to an epidemic or other reasons (for example, a large magnitude earthquake), unlike studies at the macroeconomic level.

Economic lockdown of a mega city with high production and consumption capacities will cause a great economic loss not only to itself but also to its neighbours. With the decrease of the gross domestic product of the cities, per capita income will decrease, unemployment will increase and other problems will come along.

But the problems are not just about mega-cities and their neighbours. The damage caused by the lockdown of a mega city will go beyond what we have calculated. Because, when supply chain is broken, the damage will spread to the whole country starting from the neighbours of Istanbul and Izmir. The speed of this spread in the country will also be very high.

When we consider Turkey's economic and regional conditions, the spillover economic costs of locking a mega city is very high. But whatever the price, when/if necessary, public authorities should not hesitate to lock a mega city or the whole country to protect human life since the price of a person's life cannot be measured with money.

In the short term, apart from the financial steps and regulations that will be taken to cover the costs of locking mega cities, another aspect of the issue comes up in the long term. Another dimension of the issue is related to regional economic inequalities and imbalances which have been going on for many years in Turkey. 
Spatial Spillover Effects of Mega-City Lockdown Due to Covid-19 Outbreak: Evidence from...

Successful results have not been achieved in terms of reducing the migration from the Eastern cities to the cities in the West and the economic development of Eastern and South Eastern Anatolia.

Western Anatolian cities are more developed in terms of factors such as employment, production and consumption capacity, qualified employees, etc. These dynamics pose a big problem both for the rapid spread of the epidemic diseases and in the case of a potential lockdown. If regional inequalities are reduced, potential negative effects of a lockdown will be much less.

In this context, more efforts should be made to eliminate regional inequalities and imbalances in order to deal more effectively with similar potential threats that might arise in the coming years.

\section{References}

Acar, S., Bilen-Kazancik, L., Meydan, M.C. \& Işık M. (2017). Socio-Economic Development Ranking of Provinces and Regions - Research Report (originally in Turkish), Ministry of Industry and Technology, General Directorate of Development Agencies, Report Number: 3, Ankara, 2017. Retrieved from https://www.sanayi.gov.tr/bolgesel-kalkinma-faaliyetleri/analitikcal\%C4\%B1smalar/01123b

Açıkgöz, Ö., \& Günay A. (2020). The Early Impact of the Covid-19 Pandemic on the Global and Turkish Economy", TUBITAK - Turkish Journal of Medical Sciences, 50, 520-526. https://doi.org/10.3906/sag-2004-6

Akcigit U., \& Akgunduz, Y.E. (2020). Geographic Propogation of Covid-19 Driven Demand Shocks in Turkey. Retrieved May 01, 2020 from https://static1.squarespace.com/static/5ea248ab088c8a2eba15d2d1/t/5eaa67134f2f3e5a0 1d4fdd1/1588225812804/covid19 propogation.pdf.

Altay H., \& Çelebioğlu, F. (2015). The Impacts of Political Terrorism on Gross Domestic Product in Eurasia: A Spatial Data Analysis. Eurasian Journal of Business and Economics, 8(15), 21-37. https://doi.org/10.17015/ejbe.2015.015.02

Anselin, L. (1988). Spatial Econometrics: Methods and Models, Kluwer, Dordrecht. https://doi.org/10.1007/978-94-015-7799-1

Anselin, L. (1995). Local Indicator of Spatial Association-LISA. Geographical analysis, 27 (2), 93-115. https://doi.org/10.1111/j.1538-4632.1995.tb00338.x

Anselin, L. (2003). Spatial Econometrics. In: Baltagi, B.H., Companion to Theoretical Econometrics, Blackwell Publishing Ltd., https://doi.org/10.1002/9780470996249

Anselin, L. (2005). Exploring Spatial Data with GeoDa: A Workbook, Spatial Analysis Laboratory, University of Illinois, Urbana-Champaign. Retrieved from http://sal.uiuc.edu/ and Revised Version at Center for Spatially Integrated Social Science, http://www.csiss.org/.

Anselin, L., Bera, A.K. (1998). Spatial Dependence in Linear Regression Models with an Introduction to Spatial Econometrics, In: Ullah, A. \& Giles, D.E.A. (Eds.), Handbook of Applied Economic Statistics, (Statistics: A Series of Textbooks and Monographs) (pp. 237-289). CRC Press. 
Anselin, L., Sridharan, S., \& Gholston, S. (2007). Using Exploratory Spatial Data Analysis to Leverage Social Indicator Databases: the Discovery of Interesting Patterns, Social Indicators Research, 82(2), 287-309. https://doi.org/10.1007/s11205-006-9034-x

Anselin, L., Syabri I., \& Kho Y. (2006). GoDA: An introduction to Spatial Data Analysis, Geographical Analysis, 38, 5-22. https://doi.org/10.1111/i.0016-7363.2005.00671.x

Arezki, R., \& Nguyen, H. (2020). Novel Coronavirus Hurts the Middle East and North Africa through Many Channels, In: Baldwin, R. \& di Mauro, B.W. (Eds.) Economics in the Time of COVID-19 (pp. 53-58). CEPR Press, London, UK.

Atkeson, A. (2020). What Will Be the Economic Impact of Covid-19 in the US? Rough Estimates of Disease Scenarios, Working Paper 26867. Retrieved March 29, 2020 from http://www.nber.org/papers/w26867. https://doi.org/10.3386/w26867

Baldwin, R., \& Tomiura, E. (2020). Thinking ahead about the Trade Impact of COVID-19, In: Baldwin, R. \& di Mauro, B.W. (Eds.) Economics in the Time of COVID-19 (pp. 59-71). CEPR Press, London, UK.

Beck, T. (2020). Finance in the Times of Coronavirus, In: Baldwin, R. \& di Mauro, B.W. (Eds.) Economics in the Time of COVID-19 (pp. 73-76). CEPR Press, London, UK.

Celebioglu, F. (2010). Regional Disparity and Clusters in Turkey: A Lisa (Local Indicators of Spatial Association) Analysis. Dumlupınar Üniversitesi Sosyal Bilimler Dergisi, 28, 35-48.

Celebioglu, F., \& Dall'erba, S. (2010). Spatial Disparities across the Regions of Turkey: An Exploratory Spatial Data Analysis. The Annals of Regional Science, 45(2), 379-400. https://doi.org/10.1007/s00168-009-0313-8

Elgin, C., Basbug, G., \& Yalaman, A. (2020). Economic Policy Responses to a Pandemic: Developing the COVID-19 Economic Stimulus Index, Covid Economics: Vetted and Real Time Papers (3), 40-54.

Fernandes N. (2020). Economic Effects of Coronavirus Outbreak (COVID-19) on the World Economy. Retrieved April 19, 2020 from https://ssrn.com/abstract=3557504. https://doi.org/10.2139/ssrn.3557504

GeoDa: Spatial Regression (2020). Spatial Structures in the Social Sciences, Retrieved February 20, 2020 from https://s4.ad.brown.edu/Resources/Tutorial/Modul2/GeoDa3FINAL.pdf.

Gezici, F., \& Hewings, G.J.D. (2004). Regional Convergence and the Economic Performance of Peripheral Areas in Turkey, Review of Urban \& Regional Development Studies, 16(2), 113-132. https://doi.org/10.1111/i.1467-940X.2004.00082.x

Guerrieri, V., Lorenzoni, G., Straub, L., \& Werning, I. (2020). Macroeconomic Implications of COVID-19: Can Negative Supply Shocks Cause Demand Shortages?, NBER Working Paper No. 26918. Retrieved April 28, 2020 from http://www.nber.org/papers/w26918. https://doi.org/10.2139/ssrn.3570096

Guliyev, H. (2020). Determining the Spatial Effects of COVID-19 Using the Spatial Panel Data Model, Spatial Statistics 38, 100443. https://doi.org/10.1016/i.spasta.2020.100443.

Huang, R., Liu, M., \& Ding, Y. (2020). Spatial-Temporal Distribution of COVID-19 in China and Its Prediction: A data-Driven Modeling Analysis, Journal of Infection in Developing Countries, 14(3), 246-253, https://doi.org/10.3855/jidc.12585

Inoue, H., \& Todo, Y. (2020). The Propagation of the Economic Impact through Supply Chains: The Case of a Mega-City Lockdown against the Spread of COVID-19. Retrieved April 20, 2020 from https://ssrn.com/abstract=3564898. https://doi.org/10.2139/ssrn.3564898 
Spatial Spillover Effects of Mega-City Lockdown Due to Covid-19 Outbreak: Evidence from...

Kang D., Choi H, Kim, J.H., \& Choi, J. (2020). Spatial Epidemic Dynamics of the COVID-19 Outbreak in China. International Journal of Infectious Diseases, 94, 96-102. https://doi.org/10.1016/i.ijid.2020.03.076.

Lustig, N., \& Mariscal, J. (2020). How COVID-19 Could be Like the Global Financial Crisis (or Worse). In: Baldwin R. \& di Mauro B. W. (Eds.), Mitigating the COVID Economic Crisis: Act Fast and Do Whatever It Takes. CEPR Press, London, UK, 185-190.

McKibbin, W., \& Fernando, R. (2020a). The Economic Impact of COVID-19. In: Baldwin R. \& di Mauro W. B. (Eds.), Mitigating the COVID Economic Crisis: Act Fast and Do Whatever It Takes. (pp. 45-51) CEPR Press, London, UK.

McKibbin, W., \& Fernando, R. (2020b). The Global Macroeconomic Impacts of COVID-19: Seven Scenarios", CAMA Working Paper 19/2020. Retrieved March 23, 2020 from https://ssrn.com/abstract=3547729. https://doi.org/10.2139/ssrn.3547729

Ministry of Industry and Technology of Turkey (2020) Entrepreneurial Information System of the Ministry of Industry and Technology. Retrieved April 25, 2020 from https://gbs.sanayi.gov.tr/AnaSayfa.aspx.

Özatay, F., \& Sak, G. (2020a). What Can We Do to Manage the Economic Consequences of COVID-19?, Economic Policy Research Foundation of Turkey (TEPAV), Policy Note: N202006, Retrieved from https://www.tepav.org.tr

Özatay, F., \& Sak, G. (2020b). COVID-19 Salgını Bir Değil, Bir Kaç Çeyrek Sürerse Ne Olur?, Economic Policy Research Foundation of Turkey (TEPAV), Policy Note: N202015, April2020, Retrieved April 23, 2020 from https://www.tepav.org.tr.

Özatay, F., \& Sak, G. (2020c). What If Turkey Imposes a Curfew Due To COVID-19", Economic Policy Research Foundation of Turkey (TEPAV), Policy Note: N202008. Retrieved April 24, 2020 from https://www.tepav.org.tr.

Ozili, P., \& Arun, T. (2020). Spillover of COVID-19: Impact on the Global Economy. Retrieved April 22, $2020 \quad$ from $\quad$ https://ssrn.com/abstract=3562570. https://doi.org/10.2139/ssrn.3562570

Sumner, A., Hoy, C., \& Ortiz-Juarez, E. (2020). Estimates of the impact of COVID-19 on Global Poverty, United Nations University, WIDER Working Paper 2020/43. https://doi.org/10.35188/UNU-WIDER/2020/800-9

Taymaz, E. (2020). An ex-ante policy impact analysis for Turkey (originally in Turkish). Retrieved April 08, 2020 from https://sarkac.org/2020/04/covid19-tedbirlerinin-turkiyeekonomisine-etkisi-cozum-onerileri/.

Toda, A. A. (2020). Susceptible-infected-recovered (sir) dynamics of covid-19 and economic impact. arXiv preprint arXiv:2003.11221.

Turkish Exporters Assembly-TiM (2020). Export Numbers of Provinces, Retrieved April 25, 2020 from https://www.tim.org.tr/en/export-export-figures.

TURKSTAT (2020). Population of Provinces by Years 2000-2019. Retrieved April 14, 2020 from http://www.turkstat.gov.tr/PreTablo.do?alt id=1059.

TURKSTAT (2020). Province based Gross Domestic Products. Retrieved April 15, 2020 from https://data.tuik.gov.tr/Bulten/DownloadlstatistikselTablo?p=JFvsl/Gs8zW5PoXP1EbYn4l9eg55Aa IWpRGY4hdv5imUA/33e1h9HevA5ifrZ/P1\&p2=KjruOLDCQX/hD7pBuoE8U6tbve7J3cqnr8XvA4Uqt YPFU1jthtPuT9GOP2MEpD9I\&type=1. 


\section{Fatih CELEBIOGLU}

Voth, J. (2020). Trade and Travel in the Time of Epidemics, In: Baldwin, R. \& di Mauro, B.W. (Eds.) Economics in the Time of COVID-19, CEPR Press, London, UK.

World Health Organization (2020). Situation Report - 102. Retrieved May 01, 2020 from https://www.who.int/emergencies/diseases/novel-coronavirus-2019/situation-reports/

Yigit, A. (2020). Are Covid-19 Cases Independent of the City Sizes?" MPRA Paper No. 99697, Retrieved April 23, 2020 from https://mpra.ub.uni-muenchen.de/99697/

\section{Appendix 1. Map for Locations and Names of the Provinces (totally 81) in Turkey}

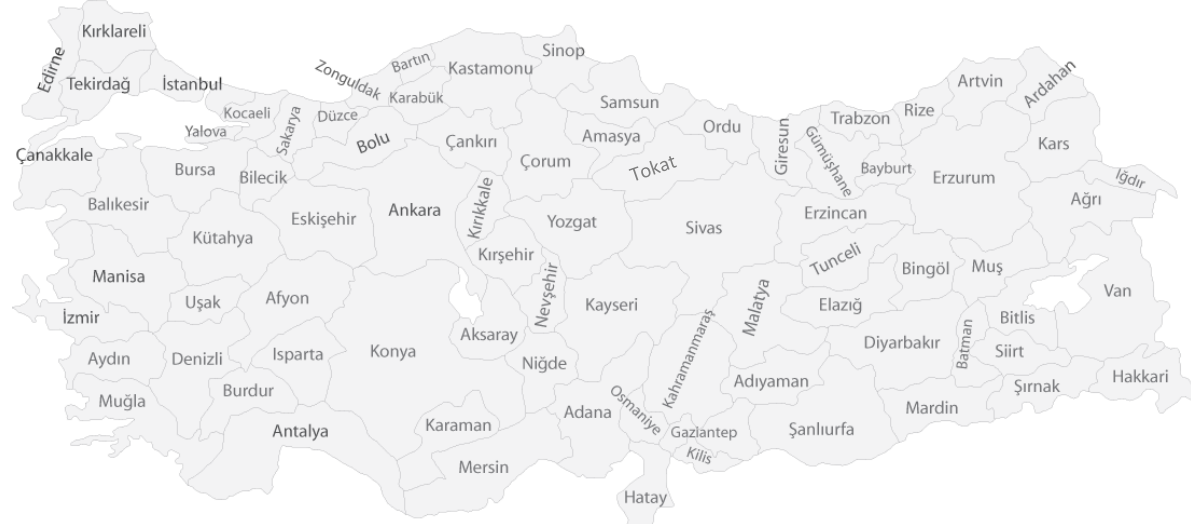

